\title{
A SYNERGISTIC APPROACH TO MICROBIAL PRESENCE ON CONCRETE: CLEANING AND CONSOLIDATING EFFECTS
}

De Belie Nele ${ }^{1}$, De Muynck Willem ${ }^{1}$, Verstraete Willy ${ }^{2}$

1 Magnel Laboratory for Concrete Research, Dept. of Structural Engineering, Ghent University, Technologiepark Zwijnaarde 904, B-9052 Ghent, Belgium; De Belie Nele: Prof. Dr. ir.; De Muynck Willem: Ph.D. student; tel. +32 926455 35, fax: +32 926458 45; email: nele.debelie@ugent.be

${ }^{2}$ Laboratory of Microbial Ecology and Technology (LabMET), Ghent University, Coupure Links 653, B-9000 Gent, Belgium; Willy Verstraete: Prof. Dr. ir.

\section{SUMMARY}

Biological techniques for cleaning and repair of concrete and stone can be an ecological alternative for traditional conservation techniques. Weathered concrete samples fouled by lichens were treated with Thiobacillus bacteria and an appropriate nutrient, by submersion or sprinkling. The general effect of cleaning was documented by the use of colorimetry and microscopy. For remediation of decayed concrete, biomineralisation of mortar samples of different porosity by ureolytic sludge was tested. For the most porous mortar samples and when urea, nutrient broth and an external calcium source were provided, the amount of water absorbed after 200 hours was decreased by a factor 5 compared to untreated samples. SEM and XRD analyses revealed a dense layer of calcite and vaterite crystals.

\section{INTRODUCTION}

Weathering of concrete surfaces is a complex proces, including physical, chemical and biological factors (e.g. leaching, attack by acids and salts, $\mathrm{NO}_{\mathrm{x}}, \mathrm{NH}_{3}$, hydrocarbons, microorganisms such as bacteria, mosses, algae, fungi, damage caused by humans such as graffiti). Weathering often induces an increased porosity, structural weakening of surface layers and an inattractive appearance ${ }^{1,2}$. To avoid further damage, surface treatments with water repellents such as silanes or siloxanes, or with pore blockers can be applied ${ }^{3}$. However, these and other treatments with organic or anorganic products involve some disadvantages, such as the 
different thermal expansion coefficient of the treated layers ${ }^{4,5}$, degradation with age and the need for constant maintenance ${ }^{6}$. Furthermore the use of certain solvents contributes to pollution. Another way to clean, repair or protect concrete and mortar surfaces is to use biological processes, which have a more ecological character ${ }^{7-9}$. In the current research, the action of living bacteria is used to clean, protect and repair concrete elements.

\section{BACTERIAL CLEANER}

The removal of biological and anorganic fouling and graffiti from concrete surfaces, is mainly performed by overpainting, water- or sandblasting or by using laser techniques ${ }^{10,11}$. These methods commonly cause aesthetic damage, because the treatments are local and the surface texture and looks of repaired areas differ from the original texture. Furthermore, irritative symptoms of the eyes and upper respiratory tract have been noticed among graffiti removers using organic solvents ${ }^{12}$. In this paper the application of sulphur oxidising micro-organisms for selective etching of the surface is investigated. A biological sulphur solution (Thio-S), consisting of a mixed culture of the sulphur oxidising bacteria Thiobacilli with appropriate nutrients, can be used for this purpose ${ }^{13}$. Thiobacilli are able to obtain energy out of the oxidation of elementary sulphur and reduced inorganic sulphur bonds to sulphuric acid. Sulphuric acid is released gradually, causing only limited damage to the underlying concrete. An optimisation of the dosage of biological sulphur, nutrients, and the way of application is aimed for.

\subsection{Materials}

Samples were taken from ordinary portland cement (OPC) concrete, fouled with lichens and atmospheric pollution forming a black patina. The lichens were characterised as Lecanora albescens, a white lichen common on mortars and calcareous stone; and Candelariella aurella, a dark grey crust with orange apothecies. The concrete samples were small cubes with sides of approximately $4 \mathrm{~cm}$, having at least one fouled plane. In the first experiment, performed at $20^{\circ} \mathrm{C}$, the so-called Thio-S consortium was applied when the micro-organisms had reached the late stationary growth phase. The initial $\mathrm{pH}$ of the solution amounted to 1.01.2. The nutrient consisted of $10 \mathrm{~g} / \mathrm{l}$ powdered sulphur (S), $0.1 \mathrm{~g} / 1 \mathrm{NH}_{4} \mathrm{Cl}, 3.0 \mathrm{~g} / 1 \mathrm{KH}_{2} \mathrm{PO}_{4}, 0.1$ $\mathrm{g} / \mathrm{MgCh} .6 \mathrm{H}_{2} \mathrm{O}$ and $0.14 \mathrm{~g} / \mathrm{l} \mathrm{CaCh} .2 \mathrm{H}_{2} \mathrm{O}$. The dissolved oxygen amount of the medium was at least $5 \mathrm{mg} / \mathrm{l}$. In a second experiment, the aim was to assess the production of metabolites in situ. The cell mass of a culture in the early exponential growth phase was harvested by - 
centrifugation. The initial $\mathrm{pH}$ of the solution was set to 7-8. During the test, which ran at $28^{\circ} \mathrm{C}$, the acidification was monitored.

\subsection{Methods}

For the first experiment, 5 heavily fouled cubes were immersed in Thio-S solution. Another 5 cubes were immersed in water in such a way that only the top plane, the fouled surface, was about $1 \mathrm{~mm}$ above the water level. Through capillarity, this surface remained continuously moist. On this surface, Thio-S was sprinkled with a brush four times a day. Furthermore, 3 cubes of each set were completely immersed in water, and 3 cubes in a sulphuric acid solution of the same initial $\mathrm{pH}$ as the Thio-S solution. These treatments all had a duration of three days per cycle. Three cycles were performed, at $20{ }^{\circ} \mathrm{C}$ and $60 \%$ relative humidity. After each treatment cycle, the cubes were dried for 4 days at $35^{\circ} \mathrm{C}$ and a relative humidity of $40 \%$.

In the second test (acidification in situ), biomass was applied at $28^{\circ} \mathrm{C}$, through immersion or through sprinkling as described above. The first cycle was stopped after nine days, since the exponential growth phase had ended at that time (end of active acidification). After this cycle, a second cleaning cycle was carried out.

A X-rite SP60 colorimeter with a measurement area of $8 \mathrm{~mm}$ diameter was used to obtain spectral reflectance graphs of the fouled surfaces. The relative reflectance of light with wavelengths ranging from $400 \mathrm{~nm}$ to $700 \mathrm{~nm}$ was measured per $10 \mathrm{~nm}$. At the beginning of the test cycles, and after the drying period of 72 hours at $35^{\circ} \mathrm{C}$ following each treatment cycle, three reflectance measurements were taken, evenly distributed over the fouled surface of each concrete cube. In the case of concrete, the measured colours are all grey values, which results in a more or less horizontal reflectance graph. Cleaning should result in a higher curve (lighter grey), approaching the reflectance curve of clean concrete (approximated by the saw planes in between the aggregates). The spectra can also be represented by tristimulus values $\mathrm{L}^{*} \mathrm{a}^{*} \mathrm{~b}^{*}$. $\mathrm{L}^{*}$ values range from black (0) to white $(+100)$, while $\mathrm{a}^{*}$ and $\mathrm{b}^{*}$ values represent green (-) to red (+), and blue (-) to yellow (+) respectively. Each colour can be characterised as a point in in the $\mathrm{L}^{*} \mathrm{a} * \mathrm{~b} *$ colour space, and a colour difference can be expressed as the distance between two points $\Delta \mathrm{E}^{*}$ ab. An increase in the colour difference between fouled and treated concrete (and a decrease in $\Delta \mathrm{E}^{*}$ ab between treated and "clean" concrete (horizontal lines in Fig. 1) indicates a more effective cleaning of the concrete surface.

\subsection{Results}


In Fig. 1, the colour difference $\Delta \mathrm{E}^{*}$ ab between fouled and cleaned concrete is shown. The first tests pointed out that the Thio-S was very sensitive to desiccation, but still in the sprinkling treatments the surface remained wet enough for the culture to be effective, although in comparison to the immersed treatments, only a very limited amount of Thio-S (a few drops 4 times a day) was used. After 3 cycles gypsum formation was apparent, especially in the case of the immersion treatment (Fig. 2). This resulted in a whiter colour than for "clean" concrete (Fig. 1).

In a second experiment on in situ acidification, after one cycle of nine days, an effect was noticeable on the specimens of the sprinkling treatment (Fig. 1 - right). No significant effect was apparent on the specimens that underwent the immersion treatment. This was probably due to the more limited diffusion of $\mathrm{CO}_{2}$ and $\mathrm{O}_{2}$ to the submersed samples. Presumably, the sprinkling treatment provided a good environment for the organisms to grow and to perform their cleaning action, provided that the humidity was sufficient. In the second cycle, the biomass was put directly on the samples used for the sprinkling treatment, and only the medium was sprinkled on intermittently as described above. This procedure allowed reaching the reference value of the clean concrete. For the immersed treatment, the second cycle was more effective than the first cycle, although the effect remained limited.

A more elaborate discussion of the application of this technique on heavily as well as moderately fouled cubes with ordinary portland cement or blastfurnace slag cement is presented by De Belie et al. ${ }^{14}$.

The application of Thio-S on façades should be adequately controllable. The deterioration effect of chemolithotrophic bacteria under actual building conditions will probably be minimal, since they are very sensitive to desiccation and need plenty of substrate, i.e. sulphur to oxidise. In the stationary growth phase, when food is lacking, the bacteria exert almost no effect. Further research will also focus on the development of a convenient procedure for the application of the Thio-S on large building surfaces, for instance using a carrier material.

\section{BACTERIAL BUILDER}

Biomineralisation is based on the ability of bacteria to promote the precipitation of carbonates $^{15}$. This results from their ability to create an alkaline environment by various 
physiological processes (a.o. photosynthesis, sulphate reduction). Furthermore they influence precipitation by $\mathrm{CO}_{2}$-production, increase of $\mathrm{Ca}$-concentration and by forming a nucleation site for crystals. Biomineralisation technologies have already been used for consolidation of sand columns ${ }^{16}$ and for repair of limestone monuments ${ }^{15,17,18}$. The procedure, developed by Le Métayer-Levrel et al. ${ }^{9}$ for repair of limestone monuments, results in the formation of a superficial calcareous coating scale, the 'biocalcin', composed mainly of encrusted bacterial bodies mixed with carbonate excretes. In contrast to chemical treatments, the protection acquired tends to increase with age ${ }^{19}$. As application of biomineralisation technologies is up to now mainly limited to limestone surfaces, in the current research a procedure for concrete and mortar surfaces is under investigation A good repair layer should allow maintaining the original looks of the building, restoring the cohesion, and reducing the water permeability and porosity. In earlier work by our research groups, criteria for the selection of calciumprecipitating Bacillus sphaericus strains were established. Currently the effect of the application of ureolytic sludge (cheaper than pure bacteria cultures and allowing fast biomass production) was determined.

\subsection{Materials and methods}

Cubes with sides of $40 \mathrm{~mm}$ were taken from standardized mortar prisms of 40 x 40 x $160 \mathrm{~mm}$, prepared with ordinary Portland cement (OPC). Prisms were made with water-to-cement ratios (w/c) of $0.5,0.6$ and 0.7 , to induce a varying porosity. Ureolytic sludge was obtained through cultivation of active sludge, obtained from an aerobic sewage water treatment plant, in a semi continuous active sludge (SCAS) reactor. The dry matter content and the concentration of volatile organic compounds amounted to $20.68 \pm 1.14 \mathrm{~g} / \mathrm{l}$ and $13.8 \pm 1.01 \mathrm{~g} / \mathrm{l}$ respectively. On one surface of the mortar cubes a paste of centrifuged ureolytic sludge of 0.5-1 mm thickness was applied. After 10 minutes settling, the mortar cubes were immersed in solutions of varying composition in order to investigate the effects of the provided nutrient and of an external calcium source (Table 1). The concentration of the different medium components per treated surface area was the same in all experiments (e.g. $0.105 \mathrm{~g}$ $\mathrm{CaCl}_{2} \cdot 2 \mathrm{H}_{2} \mathrm{O}$ per $\mathrm{cm}^{2}$ of mortar surface). The cubes were removed from the solution after deposition of a crystalline layer on the surface, which was generally after 2 to 3 days.

To determine the increase in water penetration resistance obtained by depositing the $\mathrm{CaCO}_{3}$ layer, a modified version of the sorptivity test (NBN B 05-201), was carried out. The mortar specimens were coated with polysiloxane and silicon paint at the four edges adjacent to the 
treated side, to ensure unidirectional absorption. They were dried at $70^{\circ} \mathrm{C}$ in a ventilated kiln, establishing a mass equilibrium of less than $0.1 \%$ between two measurements at 24 hour intervals. The specimens were then exposed to $10+/-1 \mathrm{~mm}$ of water with the treated side facing downwards, in an atmosphere of $20^{\circ} \mathrm{C}$ and $60 \%$ relative humidity. At regular times t, the surface-dry mass $\left(m_{t}\right)$ was determined. After the last measurement $(200 \mathrm{~h}$ of capillary water absorption) the specimens were dried at $70^{\circ} \mathrm{C}$ and the mass $\left(\mathrm{m}_{1}\right)$ determined. Afterwards, a vacuum saturation was performed and the surface-dry mass $\left(m_{v}\right)$ was measured. The capillary water absorption at time $t\left(E_{c, t}\right)$, the water absorption under vacuum $\left(E_{v}\right)$, and the relative impregnation rate $\left(\mathrm{S}_{\mathrm{t}}\right)$ are expressed as:

$$
E_{c, t}=\frac{m_{t}-m_{1}}{m_{1}} \times 100(\%), \quad E_{V}=\frac{m_{v}-m_{1}}{m_{1}} \times 100(\%) \quad \text { and } \quad S_{t}=\frac{E_{c, t}}{E_{v}} \times 100(\%) .
$$

The sorptivity of the cubes is calculated as the slopes of the functions representing the volume of absorbed water per surface area, versus the square root of time.

The morphology and mineralogical composition of the deposited $\mathrm{CaCO}_{3}$ crystals were investigated with scanning electron microscopy (Jeol JSM5600LV) after gold coating with a JFC-1200 fine coater, and by X-ray diffraction (Siemens Diffractometer with BraggBrentano optics).

\subsection{Results}

For the treated cubes the lowest water/cement ratio resulted in the fastest increase of relative impregnation rate $S_{t}$ at the beginning of the experiment (slope of the $S_{t}$ versus time curve) and also the highest final value at 200 hours (e.g. for treatment 2: $\mathrm{S}_{\mathrm{t}, \text { final }}=20 \%$ for $\mathrm{w} / \mathrm{c}=0.7$ and $\mathrm{S}_{\mathrm{t}, \text { final }}=40 \%$ for $\mathrm{w} / \mathrm{c}=0.5$ ), while the untreated cubes showed an opposite trend (for treatment 4: $\mathrm{S}_{\mathrm{t}, \text { final }}=90 \%$ for $\mathrm{w} / \mathrm{c}=0.7$ and $\mathrm{S}_{\mathrm{t}, \text { final }}=80 \%$ for $\mathrm{w} / \mathrm{c}=0.5$ ) (Fig. 3). All treatments resulted in a reduction of the slope of the $S_{t}$ versus time curves and final $S_{t}$ values in comparison with untreated cubes. The largest effect was seen for the cubes with $\mathrm{w} / \mathrm{c}=0.7$ which underwent treatment 2. The slope of the curve provides information on the initial rate of water absorption, while the final impregnation rate allows one to judge the effectiveness of the treatment after prolonged exposure to water. For the cubes with lower w/c, which are normally less porous, the water absorption under vacuum $\mathrm{E}_{\mathrm{v}}$ will be lower, and therefore the $\mathrm{S}_{\mathrm{t}}$ value can be higher. This effect could be noticed for the treated cubes. The sorptivity curves of the untreated samples typically have a bilinear shape with a fast increase of sorptivity up to 5-6 hours, after which the curve levels off (Fig. 3). For the treated samples, a 
nearly linear change with a highly reduced slope, can be noticed within the measurement interval. The final sorptivity values were somewhat higher for treatment 3 (0.15-0.19 $\left.\mathrm{cm}^{3} / \mathrm{cm}^{2}\right)$ than for treatments 1 and $2\left(0.09-0.14 \mathrm{~cm}^{3} / \mathrm{cm}^{2}\right)$, which indicates the effect of an externally supplied calcium source. The differences between cubes with different w/c ratio were not significant. The most pronounced reduction in water absorption compared to untreated samples was reached for the most porous mortar $(\mathrm{w} / \mathrm{c}=0.7)$ and when urea, nutrient broth and an external calcium source were provided (treatment 2): the amount of water absorbed by the mortar samples after 200 hours was then decreased by a factor 5 .

The morphology and size of the resulting precipitates varied widely between the first and second treatme nt. Large rhombohedral grains were obtained in the absence of nutrient broth, while the presence of the latter resulted in smaller amorphous grains (Fig. 4). Crystalline rhombohedral precipitates are presumably calcite. Solution matrix composition strongly influences the resultant morphology of the precipitates as has been demonstrated in literature $^{20}$. XRD analyses identified two calcium carbonate polymorphs, calcite and vaterite. In natural environments, vaterite, a metastable polymorph of $\mathrm{CaCO}_{3}$, is relatively rare. Its presence is usually associated with active biomineralisation processes.

\section{ACKNOWLEDGEMENTS}

The financial support of the Fund for Scientific Research - Flanders (project G.0054.02) and of the Flemish Institute for the Improvement of Scientific Technological Research in the Industry (Ph.D. grant for Willem De Muynck) is gratefully acknowledged.

\section{REFERENCES}

1. Roy, S.K., Poh, K.B. and Northwood, D.O. Durability of concrete-accelerated carbonation and weathering studies. Building and environment, 1999, 34, No. 5, 597 606.

2. Brown, P.W. and Doerr, A. Chemical changes in concrete due to the ingress of aggressive species. Cement and concrete research, 2000, 30, No. 3, 411-418.

3. Loutz, S., Dinne, K. Vervuiling en verwering van steenachtige materialen door microorganismen. WTCB-tijdschrift, 2000, $2^{\text {de }}$ trimester. 
4. Pèrez, J.L., Villegas, R., Vale, J.F., Bello, M.A., Alcade, M. Effects of consolidant and water repellent treatments on the porosity and pore size distribution of limestones. In: Proceedings of the International Colloquium: Methods of Evaluating Products for Conservation of Porous Building Materials in Monuments, ICCROM, Rome, 1995, 203211.

5. Abu-Tair, A.I., Lavery, D., Nadjai, A., Ridgen, S.R. and Ahmed, T.M.A. A new method for evaluating the surface roughness of concrete cut for repair or strengthening. Construction and building materials, 2000, 14, No. 3, 171-176.

6. Camaiti, M., Borselli, G., Matteoli, U. Prodotti consalidanti impiegati nelle operazioni di restauro. Edilizia, 1988, 10, 125-134.

7. Nogami, Y., Maeda, T., Negishi, A., Sugio, T. Inhibition of sulfur oxidizing activity by nickel ion in Thiobacillus thiooxidans NB1-3 isolated from corroded concrete. Bioscience Biotechnology and Biochemistry, 1997, 61, No. 8, 1373-1375.

8. Yoshida, N., Murooka, Y., Ogawa, K. Heavy metal particle resistance in Thiobacillus intermedius 13-1 isolated from corroded concrete. Journal of Fermentation and Bioengineering, 1998, 85, No. 6, 630-633.

9. Le Métayer-Levrel, G., Castanier, S., Orial, G., Loubière, J.-F., Perthuisot, J.-P. Applications of bacterial carbonatogenesis to the protection and regeneration of limestones in buildings and historic patrimony. Sedimentary Geology, 1999, 126, 25-35.

10. Liu, K. and Garmire, E. Paint removal using lasers. Applied optics, 1995, 34, 44094415.

11. Eck, R.W. and Martinelli, D.R. Assessment and mitigation measures for graffiti on highway structures. Maintenance and management of bridge structures, 1998, 1642, 35 42.

12. Anundi, H., Langworth, S., Johanson, G., Lind, M.L., Akesson, B., Friis, L., Itkes, N., Soderman, E., Jonsson, B.A.G. and Edling, C. Air and biological monitoring of solvent exposure during graffiti removal. International archives of occupational and environmental health, 2000, 73, No. 8, 561-569.

13. De Smul, A., Dries, J., Goethals, L., Grootaerd, H. and Verstraete, W. High rates of microbial sulphate reduction in a mesophilic ethanol-fed expanded-granular-sludgeblanket reactor. Appl. Microbiol. Biotechnol., 1997, 48, 297-303.

14. De Graef, B., De Windt, W., Dick, J., Verstraete, W. and De Belie, N. Cleaning of concrete fouled by lichens with the aid of Thiobacilli. Materials and Structures, 2005, 38, $875-882$. 
15. Boquet, E., Boronat, A., Ramos-Cormenzana, A. Production of calcite (calcium carbonate) crystals by soil bacteria is a common phenomenon. Nature, 1973, 246, 527 529.

16. Ferris, F.G. and Stehmeier, L.G. USA Patent Bacteriogenic mineral plugging, 1992, US5143155

17. Adolphe, J.-P., Loubière, J.-F., Paradas, J. and Soleilhavoup, F. Procédé de traitement biologique d'une surface artificielle, 1990, European patent $\mathrm{N}^{\circ}$ 90400G97.0.

18. Tiano, P., Biagiotti, L. and Mastromei, G. Bacterial bio-mediated calcite precipitation for monumental stones conservation: methods of evaluation. Journal of Microbiological Methods, 1999, 36, 139-145.

19. Castanier, S., Le Metayer-Levrel, G. and Perthuisot, J. Bacterial roles in the precipitation of carbonate minerals. In: Microbial Sediments (ed. R.Riding). Springer, Berlin, 1999.

20. Warren, L.A., Maurice, P.A., Parmar, N. and Ferris, F.G. Microbially Mediated Calcium Carbonate Precipitation: Implications for Interpreting Calcite Precipitation and for Solid-Phase Capture of Inorganic Contaminants. Geomicrobiology Journal, 2001, 18, 93-125. 
Table 1 Overview of the different test series

\begin{tabular}{lcccc}
\hline Treatment & 1 & 2 & 3 & 4 \\
Cement type & OPC & OPC & OPC & OPC \\
Biomass & yes & yes & yes & no \\
Nutrient medium $(\mathrm{g} / \mathrm{l})$ & & & & \\
$\mathrm{CaCl}_{2} 2 \mathrm{H}_{2} \mathrm{O}$ & 90 & 90 & - & - \\
Urea & 25 & 25 & 25 & - \\
Nutrient broth & - & 26 & - & - \\
\hline
\end{tabular}



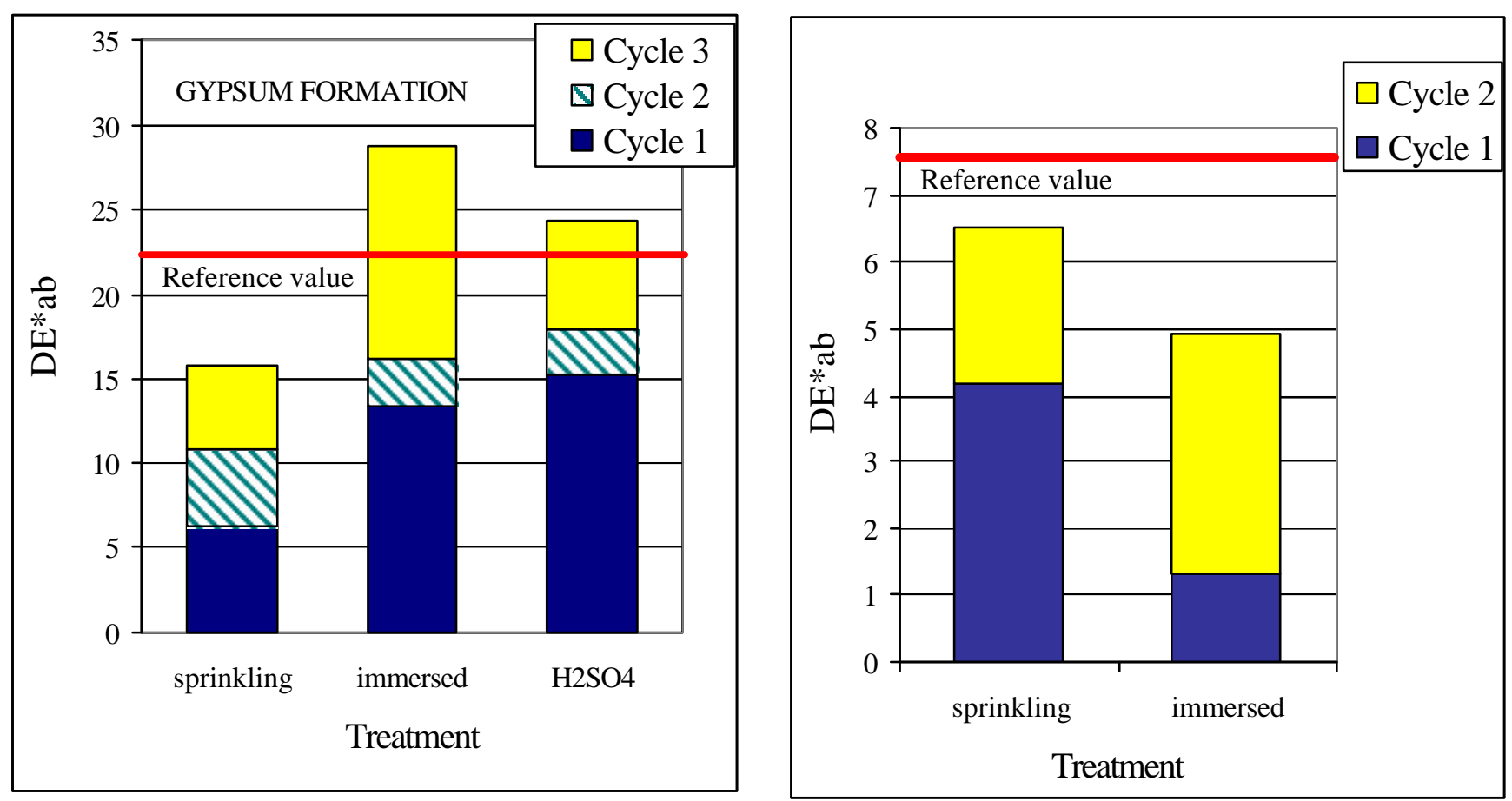

Figure 1 Left: Colour difference $\Delta \mathbf{E}^{*}$ ab between fouled and cleaned concrete for three treatment cycles of 3 days each with Thio-S in late stationary phase (initial $\mathrm{pH}=\mathbf{1 . 0 - 1 . 2}$ ) (average of 5 samples), and reference with $\mathrm{H}_{2} \mathrm{SO}_{4}$ (average of 3 samples); the control of 3 cubes immersed in water is not shown, since this treatment had no effect on the colour difference; right: idem for 2 treatment cycles of 9 days with Thio-S using acidification in situ (initial $\mathrm{pH}=7-8$ ) (average of 3 samples). 


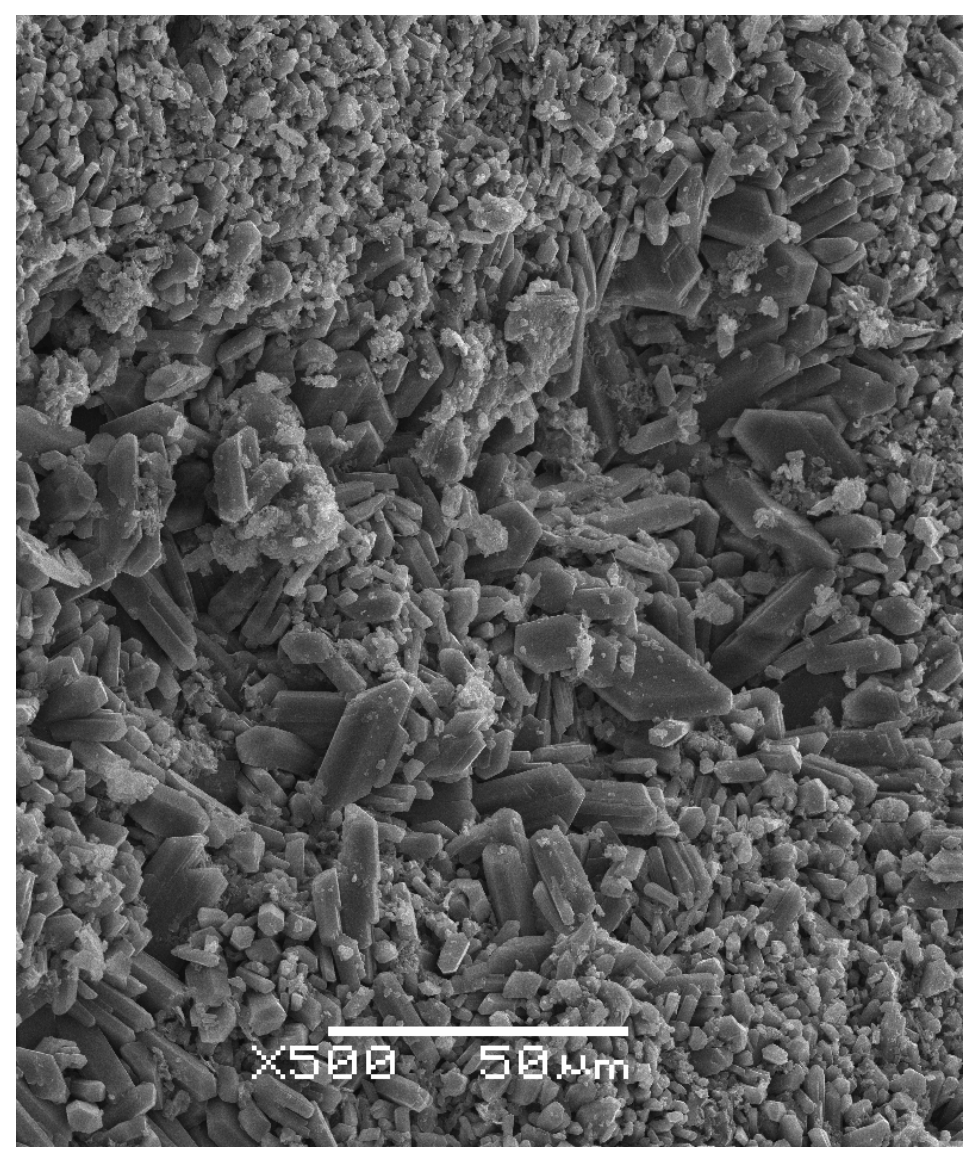

Figure 2 OPC sample after 2 cycles of immersion in Thio-S: gypsum crystals 

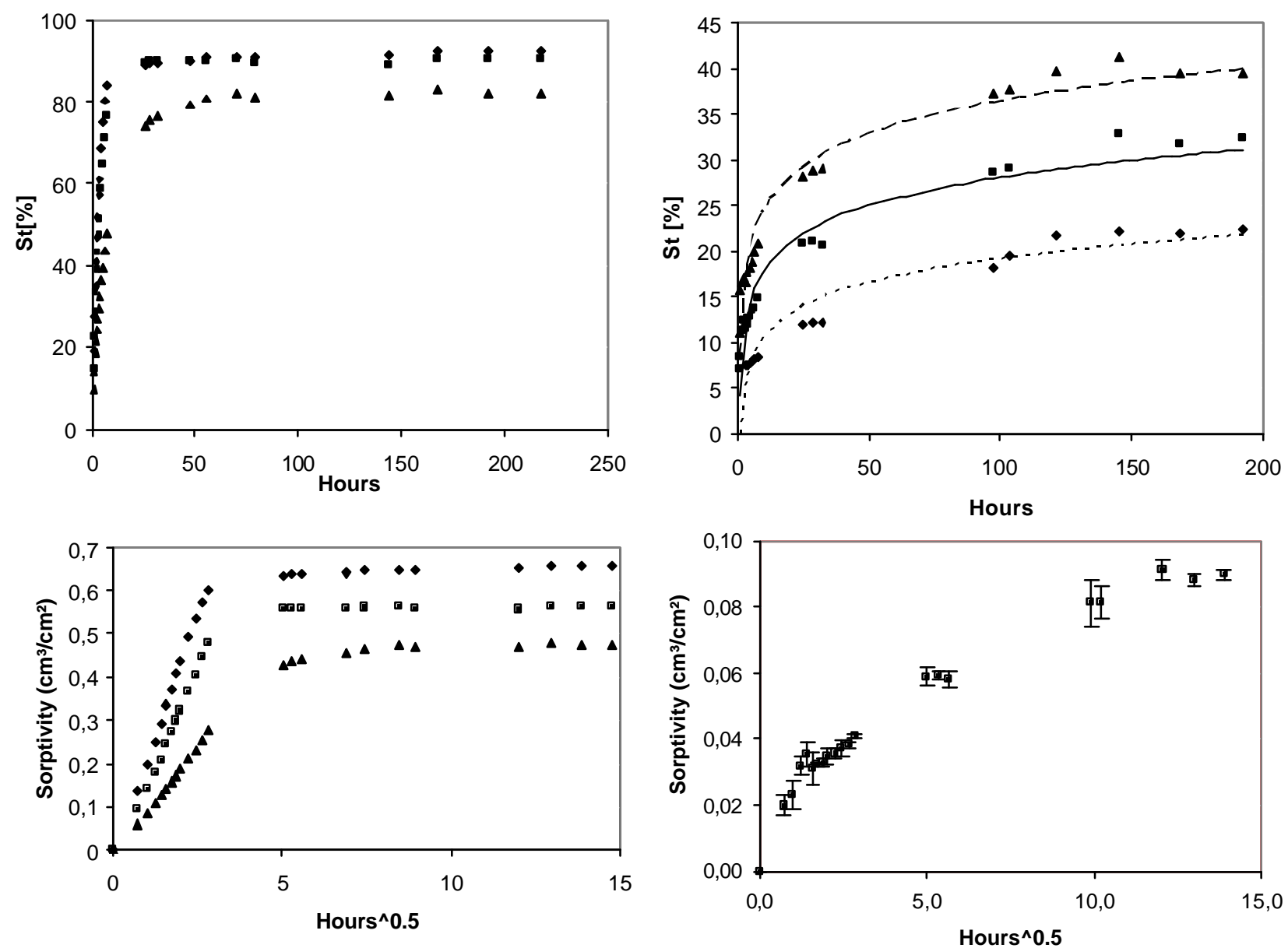

Figure 3 Relative impregnation rate $S_{(}$(top) and sorptivity (bottom) for untreated cubes (left), and for cubes from the second treatment (right) (w/c: $0.5 \Delta ; 0.6 \square ; 0.7 \diamond)$ 

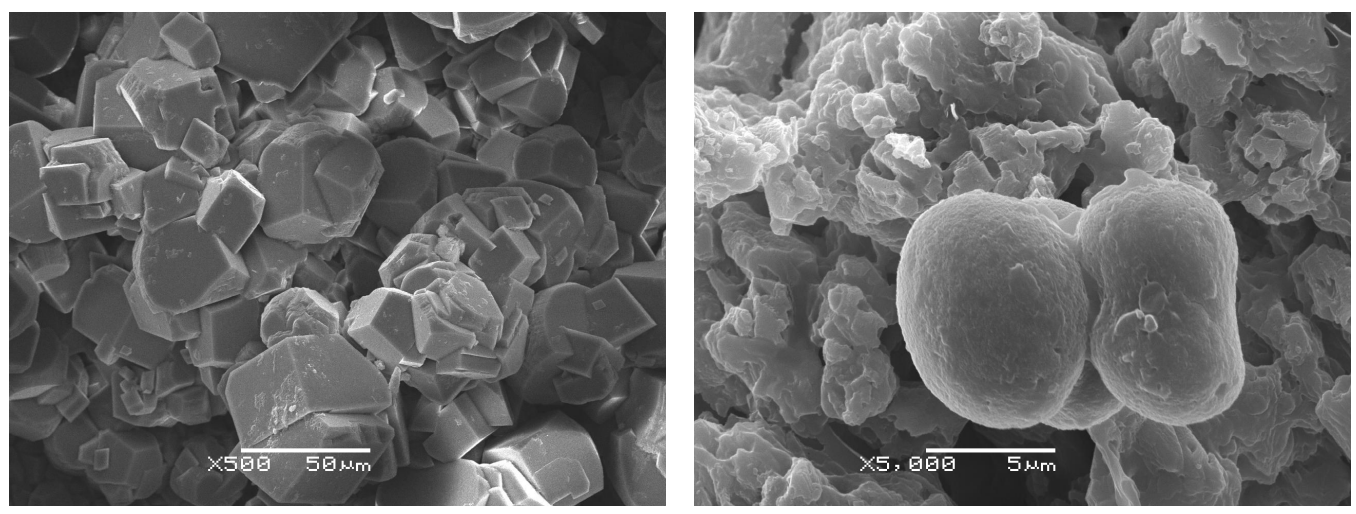

Figure 4 Microbiological calcite precipitation on the surface of a mortar cube: treatment 1 in the absence of nutrient broth (left), treatment 2 in presence of nutrient broth (right). 